\title{
Addiction and Psychology
}

\author{
Robert F Kronick* \\ Department of psychology, university of Tennessee, [Knoxville, United States
}

*Corresponding author: Robert F Kronick, Department of psychology, university of Tennessee, [Knoxville, United States.

Received Date: February 26, 2020

Published Date: March 20, 2020

\section{Introduction}

I have lived and worked in the Appalachian south for fifty years. In the 1960s I worked with rural mountain folk in the mountains of western North Carolina. During this time, I took a master's degree in social psychology at Appalachian State University. This was a blended degree of Sociology and Psychology. This interdisciplinary degree paired with applied experience in communities with cultures different from my own over fifty years. I learned the importance of culture in counseling as well as psychology. Years later, I met Paul Pedersen [1]. who averred that culture was a fourth force in these fights? During the 1960s and 1970s, I learned the influence of John C. Campbell's declaration that hillbillies don't like being told what to do by outsiders. I certainly was an outsider currently as I was a Floridan living in Appalachia for the first time. In 2019, I started to build a university assisted community school in a hill town of 500 people. This community is much different than the one in the 1960s. One of the biggest differences is addiction to opioids.

Addiction is rampant in these rural communities. Psychology must adjust these dynamic changes. Community psychology Lorion [2], may be the best option for psychology and addictions. Appalachian southerners have never been well received by urban/suburban America. Psychologically I felt the most adept Appalachians got up and out and left for cities such as Detroit where they were called urban hillbillies, a pejorative term at best. They were rowdy drunkards. Addition was rampant in this time and place. Once again, addiction and psychology met at the crossroads.

Once the population to be served has been determined, then psychological theories can be selected and implemented. I have found that reality therapy Glasser [3], and behaviorism Skinner [4], to be most effective with client groups I work with, especially vulnerable children. I believe these two approaches are more than suited to addiction. Culture as a fourth force is also a necessary ingredient.

\section{Discussion}

In this decade of 2020, it is now past time for psychology and the social sciences in general to become relevant to the problems of humankind, and addiction, especially to opioids, is the zenith of these problems in living. Psychology will be best served if we think of people having problems in living, not as problem people. This inhibits victim blaming Ryan [5] and leads to a systemic Bronfenbrenner [6] approach to societal issues such as addiction.

\section{Conclusion}

There is nothing so useful as a good theory Lewin [7] when it comes to the complex issues surrounding addiction. Socioeconomic status, race, gender, and location can be used as theoretical concepts to comprehend addiction and develop interventions that will eventually obliterate addiction, penultimately addiction to opioids. This special addiction to opioids is not limited to any geographical areas but runs from New Hampshire to California.

In the words of James and Willie Chambers, the Chambers brothers, the time has come today.

\section{Acknowledgement}

None.

\section{Conflict of interest}

No conflict of interest. 


\section{References}

1. Pedersen P, Pope (2010) Inclusive Cultural Empathy for Successful Global Leadership. Am Psychol 65(8): 841-854.

2. Lorion R (1974) Patent and Therapist Variables in the Treatment of Low-Income Patients. Psychol Bull 81(6): 344-354.

3. Glasser W (1965) Reality Therapy: A New Approach to Psychiatry. New York, USA.
4. Skinner BF (1971) Beyond Freedom and Dignity. New York, USA.

5. Ryan W (1971) Blaming the Victim. New York, USA.

6. Bronfenbrenner U (1979) The Ecology of Human Development. Harvard University Press, London, UK.

7. Lewin K (1951) Field Theory in Social Science. New York, USA. 